\title{
PERANCANGAN ARSITEKTUR ENTERPRISE UNTUK MENDUKUNG PROSES BISNIS MENGGUNAKAN TOGAF ARCHITECTURE DEVELOPMENT METHODE (ADM) DI STMIK DHARMA NEGARA
}

\author{
Yudi Mulyanto, Didi Rosiyadi \\ Magister Sistem Informasi, Fakultas Pasca Sarjana \\ Universitas Komputer Indonesia \\ Jalan Dipati Ukur no. 112 - 116, Bandung, Jawa Barat, Indonesia
}

$\varangle$ : mulyanto.yudi@gmail.com;

\begin{abstract}
Construction and development of enterprise architecture and information systems are appropriately planned and well designed and suit to the needs and the abilities of the organization. Good planning will provide great benefits for construction and development of enterprise architecture, both in terms of human resources, budget and organization's readiness to implement the plan. In this study did not use all the phases of TOGAF ADM, this study only uses seven from nine phases TOGAF ADM namely the preliminary phase, architecture vision phase, business architecture phase, architecture of information systems phase, technology architecture phase, opportunity and solution phase and migration planning phase. The first phase of the enterprise architecture development is the prelimary phase, output from the preliminary phase becomes input to the early phases of the TOGAF ADM phases, which is named architecture vision phase and from that input device produced the new organizational structure that will be proposed. In the next phase of business phase was also analyzed using Value Chain analysis.
\end{abstract}

Keywords - TOGAF ADM, Value Chain, architecture, enterprise, information system.

\begin{abstract}
Abstrak - Pembangunan dan pengembangan arsitektur enterprise dan sistem informasi sudah selayaknya direncanakan dan dirancang secara baik serta disesuaikan dengan kebutuhan dan kemampuan organisasi. Perancangan yang baik akan memberikan manfaat yang besar bagi pembangunan atau pengembangan arsitektur enterprise, baik dari sisi sumber daya manusia, anggaran dan kesiapan organisasi dalam melaksanakan rencana tersebut. Pada penelitian ini fase-fase dalam togaf ADM tidak digunakan seluruhnya, penelitian ini hanya menggunakan tujuh fase dari sembilan fase togaf ADM yaitu fase preliminary, fase arsitektur visi, fase arsitektur bisnis, fase arsitektur sistem informasi, fase arsitektur teknologi, fase oputunity and solution, fase migration planning. Fase pertama dari pengembangan arsitektru enterprise ini adalah fase preliminary, output dari fase preliminary menjadi inputan pada fase awal dari fase togaf ADM yaitu arsitektur visi dan dari inputan tersebut menghasilkan struktur organisasi baru yang akan diusulkan. Pada fase selanjutnya proses bisnis juga dianalisa dengan menggunakan analisis Value Chain.
\end{abstract}

Kata Kunci - TOGAF ADM, Value Chain, arsitektur, enterprise, sistem informasi

\section{PENDAHULUAN}

A. Latar Belakang

Dinamika perubahan lingkungan organisasi dan perkembangan teknologi inforamasi menuntut setiap organisasi untuk dapat melakukan adaptasi sehingga mampu menjaga kelangsungan hidup organisasi dalam jangka panjang. Perancangan sebuah enterprise architecture (EA) pada prinsipnya untuk mengadakan sebuah standarisasi dan sebagai panduan untuk merealisasikan tujuan dari organisasi. Secara umum EA dikembangkan karena didasari pertimbangan penyelarasan dengan tujuan stategik organisasi, integrasi dengan proses bisnis, memfasilitasi perubahan, mengurangi proses development, resource requirement, dan konvergensi dengan standar dalam teknologi informasi. Selain itu EA dikaitkan dengan peningkatan tata kelola, sehingga secara konseptual dapat didefinisikan sebagai basis aset informasi strategis yang menentukan misi, informasi dan teknologi yang dibutuhkan oleh organisasi [7].
B. Identifikasi Masalah

Identifikasi masalah berdasarkan permasalahan pada latar belakang di atas adalah

1) STMIK Dharma Negara belum memiliki rancangan arsitektur enterprise dan sistem informasi yang terintegrasi sebagai pendukung pencapaian tujuan bisnis dari sekolah.

2) Belum adanya Blue Print atau model arsitektur Enterprise yang akan digunakan untuk merancang dan mengembangkan sistem informasi dan teknologi informasi.

\section{Hipotesis}

Berdasarkan permasalahan yang telah dijabarkan pada identifikasi masalah serta manfaat dan fungsi dari sistem informasi di atas dapat diajukan sebuah hipotesis, yaitu STMIK Dharma Negara membutuhkan sebuah Blue Print dan Sistem Informasi sehingga unit organisasi di STMIK Dharma Negara dapat membuat keputusan teknologi informasi jangka panjang yang tepat guna dengan mempertimbangkan kepentingan STMIK Dharma Negara secara keseluruhan. 


\section{Tujuan dan Manfaat Penelitian}

\section{1) Tujuan penelitian}

Tujuan dari penelitian ini adalah untuk merancang arsitektur enterprise di STMIK Dharma Negara.

2) Manfaat penelitian

Manfaat penelitian yang dapat diperoleh dari penelitian ini adalah:

a. Memberikan gambaran blueprint sebagai landasan untuk pengembangan arsitektur enterprise dalam pengelolaan STMIK Dharma Negara.

b. Memberikan rekomendasi bagi STMIK Dharma Negara untuk membangun arsitektur enterprise pada sistem yang terintegrasi.

c. Mempermudah proses pengembangan arsitektur sistem informasi dengan tujuan untuk membentuk integritas informasi yang dikeluarkan tiap bagian atau unit.

\section{E. Batasan Masalah}

Batasan masalah yang akan dikaji dalam penelitian ini adalah sebagai berikut:

a. Pemodelan arsitektur enterprise yang akan digunakan menggunakan the open group architecture framework (TOGAF) yang meliputi:

(1) Architecture Vision.

(2) Business Architecture.

(3) Information System Architecture.

(4) Technology Architecture.

(5) Opportunities and solutions.

(6) Migration and planning.

b. Kegiatan dilakukan dalam lingkungan STMIK Dharma Negara.

\section{TINJAUAN PUSTAKA}

A. Comprehensive Review: Comparison / Perbandingan Penelitian

Tesis yang berjudul Perancangan Enterprise Architecture Menggunakan Togaf Di Direktorat Jenderal Perbendaharaan Departemen Keuangan, merupakan penelitian sebelumnya yang berkaitan dengan penelitian ini dan dijadikan acuan dalam penelitian ini [14].

\begin{tabular}{|l|lr|}
\hline \multicolumn{2}{|c|}{ Usulan penelitian } & \multicolumn{2}{|c|}{ Penelitian sebelumnya } \\
\hline 1. Penelitian ini di & 1. & Penelitian yang \\
laksanakan di bidang & dilakukan oleh Siti \\
pendidikan yaitu di & Zulaiha dengan judul \\
STMIK Dharma Negara. & Perancangan Enterprise \\
2. Metode arsitektur & $\begin{array}{l}\text { Architecture } \\
\text { enterprise yang }\end{array}$ & Menggunakan Togaf Di \\
digunakan adalah togaf & Direktorat Jendral \\
ADM sampai dengan & Perbendaharan \\
& Departemen Keuangan. \\
\hline
\end{tabular}

\begin{tabular}{|c|c|}
\hline 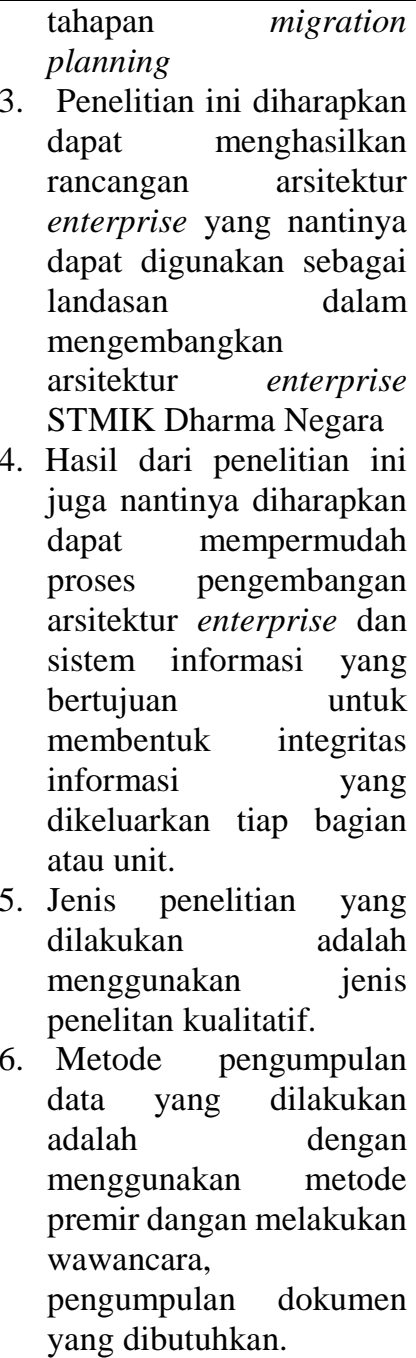 & 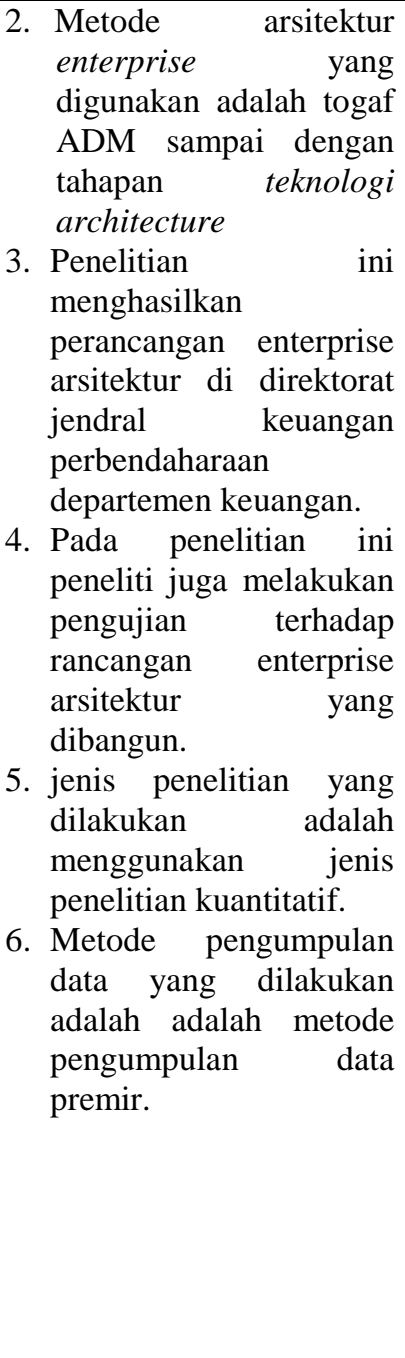 \\
\hline
\end{tabular}

\section{B. Sistem Informasi}

Sistem informasi tidak harus melibatkan komputer, sistem informasi yang melibatkan komputer biasanya disebut sistem informasi berbasis komputer (Computer Based Information System atau CBIS). Dalam praktek, istilah sistem informasi sering kali dipakai tanpa embel-embel berbasis komputer walaupun dalam kenyataannya komputer merupakan bagian yang sangat penting. Dari penjelasan tersebut dapat disimpulkan bahwa sistem informasi mencakup sejumlah komponen (manusia, komputer, teknologi informasi dan prosedur kerja). Ada sesuatu yang diproses (data menjadi informasi) dan dimaksudkan untuk mencapai suatu sasaran atau tujuan [1].

\section{Teknologi Informasi}

Teknologi informasi adalah studi atau penggunaan peralatan elektronika, terutama komputer, untuk menyimpan, menganalisis dan mendistribusikan informasi apa saja termasuk kata-kata, bilangan, dan gambar. Martin mendefinisikan 
teknologi informasi tidak hanya terbatas pada teknologi komputer (perangkat keras dan perangkat lunak) yang digunakan untuk memproses dan menyimpan informasi, melainkan juga termasuk teknologi komunikasi untuk mengirimkan informasi. Secara lebih umum Lucas menyatakan bahwa teknologi informasi adalah segala bentuk teknologi yang diterapkan untuk memproses dan mengirimkan informasi dalam bentuk elektronis, mikrokomputer, komputer, mainframe, pembaca barcode, perangkat lunak pemroses transaksi, perangkat lunak lembar kerja, peralatan komunikasi dan jaringan merupakan teknologi informasi [1].

\section{Enterprise}

Enterprise adalah sekumpulan korporat atau entitas atau lembaga dengan tugas yang mendukung entitas fungsional dan memiliki sekumpulan tujuan atau suatu perintah. Dalam konteks ini, suatu enterprise adalah divisi atau departemen dari suatu perusahaan, sekelompok organisasi yang terpisah secara geografis namun dihubungkan bersama oleh kepemilikan secara administratif, agen pemerintah (atau sekumpulan agen) pada setiap tingkat yuridiksi, sekumpulan agen pemerintah, dan seterusnya [3].

\section{E. Arsitektur}

ISO/IEC 42010:2007 mendefinisikan arsitektur sebagai dasar organisasi dari sebuah sistem, terwujud dalam komponenkomponen, hubungan satu sama lain dan lingkungan, dan prinsip-prinsip yang mengatur desain dan evolusi [4].

Menurut Electronic Industry Assocation arsitektur merupakan komponen-komponen sebuah sistem yang terdiri dari jaringan, perangkat keras dan lunak yang distrukturkan. Arsitektur dapat digambarkan sebagai blueprint TI / korporat untuk perencanaan suatu kota atau pembangunan yang besar [3].

\section{F. Arsitektur Enterprise}

Arsitektur Enterprise / Enterprise Architecture (EA) adalah kumpulan proses bisnis, aplikasi, teknologi, dan data yang mendukung strategi bisnis suatu enterprise. EA adalah suatu rencana perekaman, cetak biru dari struktur, susunan, pengaturan, pengelompokan fungsional, antar muka, data, protokol, logika fungsional, integrasi, teknologi, dari sumber IT dan dibutuhkan untuk mendukung fungsi bisnis atau misi korporat atau organisasi [3].

\section{G. TOGAF}

TOGAF merupakan kepanjangan dari The Open Group Architecture Framework. TOGAF adalah framework arsitektur yang memberikan metode dan tools untuk membantu dalam penerimaan, produksi, penggunaan, dan perawatan arsitektur enterprise. TOGAF didasarkan pada model proses iteratif yang didukung oleh best practice dan sekumpulan aset arsitektur yang bisa digunakan kembali [4]. ADM merupakan metode generik yang berisikan sekumpulan aktivitas yang digunakan dalam memodelkan pengembangan arsitektur enterprise. Metode ini juga bisa digunakan sebagai panduan atau alat untuk merencanakan, merancang, mengembangkan dan mengimplementasikan arsitektur sistem informasi untuk organisasi [4], [16].

TOGAF terdiri atas 9 (sembilan) fase yang berbentuk siklus (cycle). Pada fase ke 4 di fokuskan pengembangan arsitektur teknologi. Fase-fase dalam metode TOGAF dapat dilihat di gambar 1.

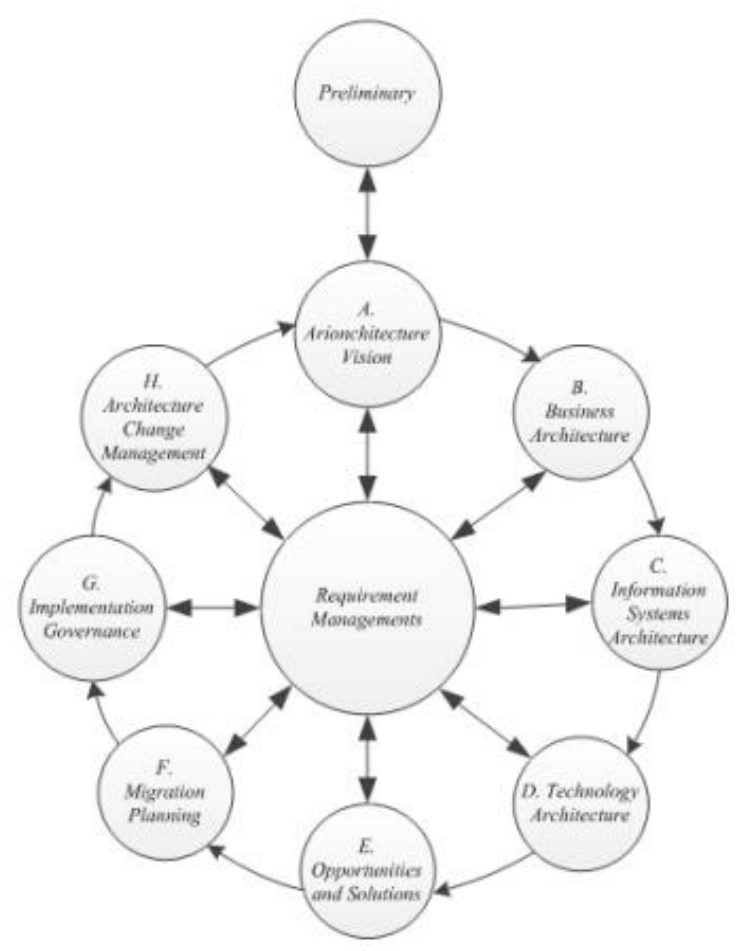

Gambar 1. Proses Pengembangan TOGAF ADM [4].

\section{H. Value Chain}

Value Chain Porter ditemukan oleh Michael Porter, Value Chain merupakan model yang digunakan untuk membantu menganalisis aktivitas-aktivitas spesifik yang dapat menciptakan nilai dan keuntungan kompetitif bagi organisasi. Fungsi dari value chain yaitu untuk mendeskripsikan cara melihat bisnis sebagai rantai aktifitas yang mengubah input menjadi output sehingga memiliki nilai bagi pelanggan [12]. Model ini mengidentifikasi poin kritis tertentu dimana perusahaan dapat menggunakan teknologi informasi yang paling efektif untuk mencapai posisi kompetitif. Value chain model melihat perusahaan sebagai sekumpulan atau rantai aktifitas dasar yang bisa menambah nilai terhadap produk atau layanan perusahaan. Aktifitas tersebut dapat dibagi menjadi aktifitas utama dan aktifitas pendukung seperti yang terlihat pada gambar 2 . 


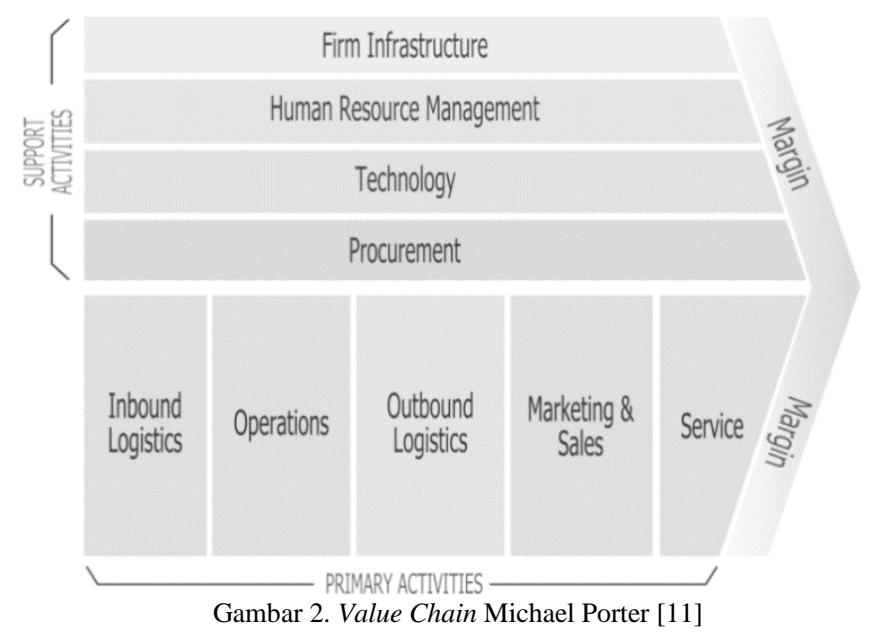

I. Unified Modeling Language (UML)

Unified Modeling Language (UML) adalah suatu bahasa yang digunakan untuk menentukan, memvisualisasikan, membangun, dan mendokumentasikan suatu sistem informasi. UML dikembangkan sebagai suatu alat untuk analisis dan desain berorientasi objek [5]. UML disebut bahasa pemodelan, bukanlah sebuah metode. Pada prinsipnya metode terdiri dari dua yaitu bahasa pemodelan dan proses. Bahasa pemodelan adalah notasi yang digunakan untuk mengekspresikan desain. Sedangkan proses menjelaskan apa saja langkah langkah yang harus dilakukan dalam melakukan desain [8].

Class adalah sebuah spesifikasi yang jika diinstansiasi akan menghasilkan sebuah objek dan merupakan inti dari pengembangan dan desain berorientasi objek. Class menggambarkan keadaan (atribut/properti) suatu sistem, sekaligus menawarkan layanan untuk memanipulasi keadaan tersebut (metoda/fungsi). Class Diagram menggambarkan struktur dan deskripsi class, package dan objek beserta hubungan satu sama lain seperti containment, pewarisan, asosiasi, dan lainlain [9].

Class Diagram terdiri dari tiga bagian yaitu nama class, atribut dan operasi / method. Bagian class diagram tersebut dapat dilihat pada gambar 3 .

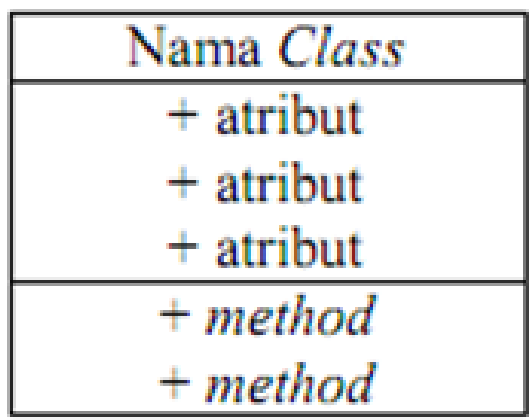

Gambar 3. Class Diagram

\section{J. Analisa SWOT}

Sebuah teknik tertentu yang disebut analisa SWOT menjadi populer dalam praktek perencanaan strategis di Amerika Serikat pada 1990-an . SWOT adalah singkatan dari strengths (kekuatan), weaknesses (kelemahan), opportunities (peluang), dan threats (ancaman). Teknik ini digunakan terbatas dalam strategis perencanaan, jika digunakan dengan benar dalam konteks rencana strategis. SWOT Analisis dapat digunakan untuk meringkas poin-poin penting dari sebuah operasi yang berkelanjutan dalam skenario dan pengetahuan dari rencana strategis [15] .

\section{METODOLOGI}

\section{A. Metodologi Penelitian}

Metodologi penelitian yang dilakukan dalam melakukan perancangan arsitektur enterprise di STMIK TI Dharma Negara dapat dilihat di gambar 4 di bawah ini:

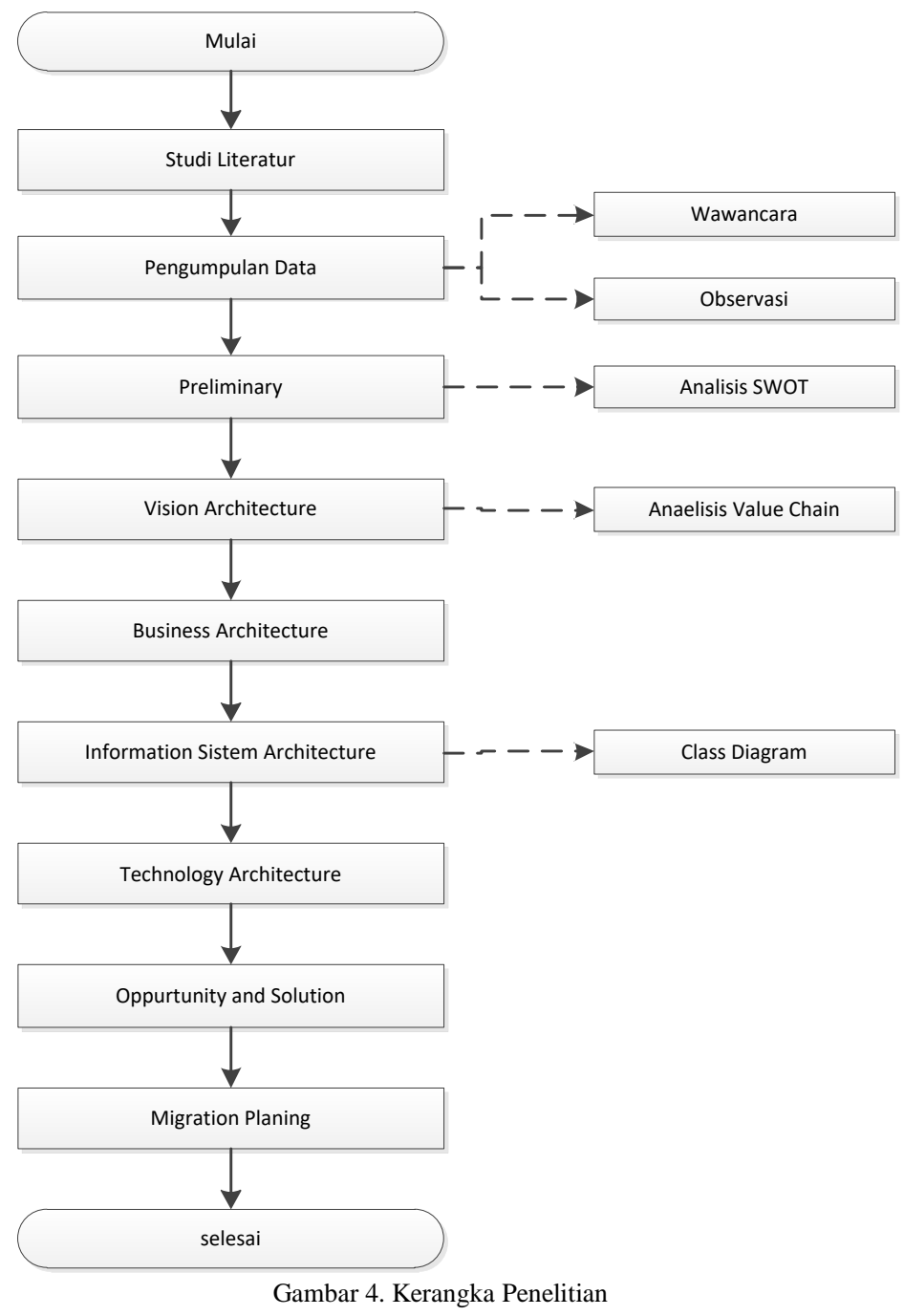




\section{B. Prosedur Penelitian}

Penelitian ini dilakukan di STMIK Dharma Negara dengan tujuan untuk mengumpulkan data yang terkait dengan perancangan arsitektur enterprise dengan menggunakan framework TOGAF ADM. Adapun langkah-langkah yang digunakan dalam melakukan penelitan ini adalah sebagai berikut:

a. Mewujudkan pengelolaan yang terencana, terorganisasi produktif, efektif, efesien dan terpercaya untuk menjamin keberlanjutan perguruan tinggi.

b. Menjalin kerjasama dengan pihak lain dalam lingkung rigional, nasional dan internasional untuk pengembangan pendidikan dan penelitian.

c. Mewujudkan sifitas akademik yang mampu menjadi teladan dalam kehidupan bermasyarakat.

\section{1) Studi Literatur}

Studi literatur dilakukan untuk mencari informasi-informasi tentang teori, metode dan konsep yang relevan dengan permasalahan. Sehingga dengan informasi-informasi tersebut dapat digunakan sebagai acuan dalam penyelesaian masalah. Studi literatur yang dilakukan dengan mencari informasi dan referensi dalam bentuk text book, literatur, informasi dari internet maupun sumber-sumber lainnya yang berkaitan dengan penelitian ini.

\section{2) Pengumpulan Data}

Pengumpulan data dilakukan untuk memperoleh informasi yang dibutuhkan dalam rangka mencapai tujuan penelitian. Tujuan yang diungkapkan dalam bentuk hipotesis merupakan jawaban sementara terhadap pertanyaan penelitian. Metode pengumpulan data bisa dilakukan dengan cara:

(1) Wawancara merupakan teknik pengumpulan data yang dilakukan melalui tatap muka dan tanya jawab langsung antara pengumpul data maupun peneliti terhadap nara sumber atau sumber data.

(2) Obrservasi merupakan pengamatan langsung terhadap organisasi yang terkait dengan kebutuhan perancangan arsitektur enterprise. Observasi adalah salah satu teknik pengumpulan data yang tidak hanya mengukur sikap dari responden namun juga dapat digunakan untuk merekam berbagai fenomena yang terjadi (situasi, kondisi).

\section{3) Fase Preliminary}

Pada fase preliminary adalah merupakan tahap awal persiapan perancangan EA. Pada fase ini ditetapkan framework yang digunakan untuk merancang EA dan identifikasi sumber daya untuk merancang EA. Adapun tahapan yang dilakukan dalam fase ini adalah sebagai berikut:

a. Identifikasi prinsip arsitektur yang digunakan dalam perusahaan. b. Penentuan framework, pada penelitian ini framework yang digunakan adalah TOGAF ADM.

c. Penentuan tools yang digunakan. Tools yang akan digunakan adalah value chain dan diagram UML.

\section{4) Fase Arsitektur Visi}

Pada Tahapan ini menentukan kebutuhan yang dibutuhkan untuk perancangan arsitektur enterprise yang meliputi:

(1) Profil organisasi

(2) Pendefinisian visi dan misi

(3) Tujuan organisasi

(4) Struktur organisasi

(5) Proses bisnis organisasi

(6) Kondisi Arsitektur saat ini

\section{5) Fase arsitektur bisnis}

Tahapan ini menentukan model bisnis atau aktivitas bisnis yang diinginkan berdasarkan skenario bisnis. Ada tiga hal yang harus dilakukan, yaitu:

(1) Menentukan sudut pandang untuk memperlihatkan bagaimana stakeholder saling berhubungan.

(2) Menentukan sumber daya yang relevan, seperti model dan pola yang digunakan menggunakan analisis value chain.

(3) Membuat matriks hubungan proses bisnis dengan organisasi

\section{6) Fase Arsitektur Sistem Informasi}

Pada tahapan ini menentukan arsitektur data dan arsitektur aplikasi. Arsitekur data lebih memfokuskan pada bagaimana data digunakan untuk kebutuhan fungsi bisnis, proses dan layanan. Teknik yang digunakan adalah Class Diagram. Pada arsitektur aplikasi lebih menekan pada bagaimana kebutuhan aplikasi direncanakan, dengan tahapan Mendefinisikan aplikasi dan Membuat model konseptual proses bisnis.

\section{7) Fase Arsitektur Teknologi}

Tahapan ini dilakukan perancangan terhadap arsitektur teknologi yang akan mendukung arsitektur enterprise meliputi perangkat keras dan perangkat lunak. Langkah langkah yang dilakukan pada tahapan ini adalah sebagai berikut:

(1) Membuat analisa kesenjangan kondisi teknologi saat ini dan kondisi teknologi yang menjadi target.

(2) Identifikasi kebutuhan teknologi sesuai dengan kebutuhan.

(3) Usulan perancangan infrastruktur dan jaringan komputer.

\section{8) Fase Peluang Dan Solusi}

Kegiatan yang dilakukan pada tahapan ini meliputi evaluasi, memilih alternative implementasi, mendefinisikan strategi implementasi dan rencana implementasi. Tahapan ini juga menekankan pada manfaat yang diperoleh organisasi dari perancangan arsitektur enterprise. Adapun tahapan yang akan dilakukan pada fase ini adalah menggabungkan dan mengulas 
hasil analisis kesenjangan dan solusi dari arsitektur bisnis, sistem informasi dan teknologi.

\section{9) Fase Perencanaan Migrasi}

Tahapan ini merencanakan proses peralihan dari sistem yang lama ke sistem yang baru agar penerapan sistem informasi yang dibangun menjadi terarah dan berjalan dengan baik. Proses migrasi ini meliputi penentuan prioritas proyek, penentuan sumber daya, dan langkah yang ditempuh untuk meminimalisir resiko akibat terjadinya perubahan.

\section{ANALISIS DAN PEMBAHASAN}

\section{A. Analisis Perancangan Arsitektur Enterprise}

Berdasarkan hasil observasi dan wawancara, didapatkan bahwa belum ada arsitektur enterprise yang dapat memenuhi kebutuhan. oleh karena itu akses informasi menjadi tidak efektif maka perlu dirancang suatu arsitektur enterprise yang efektif, cepat, dan terhubung dalam seluruh jaringan. Untuk merancang arsitektur enterprise ini diperlukan suatu kerangka kerja untuk permodelan arsitektur enterprise. Permodelan ini akan menghasilkan kerangka kerja yang dapat dijadikan acuan dalam perancangan arsitektur enterprise.

Tahapan perancangan arsitektur enterprise mengacu pada TOGAF ADM yang terdiri dari delapan fase kegiatan yang dibutuhkan dalam membangun arsitektur enterprise, akan tetapi dalam penelitian ini membatasi dengan menggunakan 7 fase, diantara lain: preliminary, architecture vision, business architecture, information system architecture, technology architecture, opportunities and solution, and migration planning.

\section{B. Fase Preliminary}

Pada tahap preliminary adalah tahap awal persiapan perancangan EA. Pada fase ini ditetapkan framework yang digunakan untuk merancang EA dan identifikasi sumber daya untuk merancang EA. Framework yang akan digunakan adalah TOGAF ADM, hal ini untuk menentukan bagaimana sebuah arsitektur sistem informasi dibangun, dipelihara dan diterapkan, dimana dalam penelitian ini mencakup 7 tahapan yaitu fase preliminary, arsitektur visi, arsitektur bisnis, arsitektru sistem informasi, arsitektur teknologi, peluang dan solusi dan perancangan migrasi. Analisis Strength, Weaknesses, Oppurtunities dan Threats (SWOT) terhadap bisnis organisasi beserta teknologi informasi pada STMIK Dharma Negara:

1) Strengths (kekuatan).

Dalam suatu sekolah tinggi pasti mempunyai kekuatan tersendiri, yang dimana kekuatan tersebut dijadikan sebagai acuan yang harus dipertahankan, dan kekuatan internal yang dimiliki STMIK Dharma Negara adalah:

a) STMIK Dharma Negara memiliki jurusan yang banyak dibutuhkan dalam dunia kerja, baik industri, maupun non industri. b) Lulusan STMIK Dharma Negara akan menguasai berbagai keahlian dalam bidang teknologi seperti: Analyst System, Website Developer, Software Engineering, E-bisnis Spesialis.

c) Semua program studi telah terakreditasi.

d) Kampus milik sendiri, lokasi dalam kota dengan suasana yang tenang dan nyaman. Jarak kurang +/- 100 meter dari angkot dan stasiun kereta api kiaracondong.

e) Fasilitas laboratorium komputer, bahasa, lab pajak dan inkubator bisnis.

f) Free Hotspot.

g) Tersedia sarana olahraga, lapangan futsal, basket dan aula.

h) Biaya kuliah dapat di angsur.

i) Dosen lulusan S2 dan S3.

j) STMIK Dharma Negara mempunyai unit kegiatan mahasiswa (UKM) yang beragam seperti : futsal, volley ball, basket, photografy, kajian islam, bulutangkis, karate, paduan suara, mapala.

2) Weaknesses (kelemahan).

Selain dari sisi kekuatan, sisi kelemahan juga harus menjadi pertimbangan bagi STMIK Dharma Negara sebagai sebuah strategi untuk menjaga eksistensi PTS. hal ini bertujuan untuk memudahkan proses evaluasi dalam kurun waktu tertentu. Seperti hal nya yang lain, ada beberapa kelemahan yang perlu di perhatikan dalam pengelolaan dunia pendidikan, termasuk oleh STMIK Dharma Negara. Kelemahan tersebut diantaranya:

a. Pendidikan:

(1) Jangka waktu penyelesaian studi yang masih relatif lama.

(2) Kompetensi lulusan yang mampu bersaing pada pasar tenaga kerja internasional masih rendah.

(3) Jumlah guru besar masih terbatas.

(4) Jumlah dan kualitas tenaga kependidikan masih teratas.

(5) Jumlah buku dan jurnal ilmiah internasional masih belum mencukupi kebutuhan optimal.

b. Bangunan:

(1) Gedung STMIK Dharma Negara yang sudah harus di renovasi.

(2) Terdapat kerusakan pada bagian-bagian tertentu gedung.

(3) Fasilitas toilet yang tidak memadai.

c. Ruangan kelas:

(1) Fasilitas ruangan yang kurang baik.

(2) Pengadaan pendingin kelas yang kurang.

(3) Kebersihan ruangan yang tidak terjaga baik.

d. Ruangan LAB Komputer:

(1) Pengadaan pendingin ruangan yang kurang.

(2) Fasilitas yang mendukung kegiatan belajar masih kurang 
(3) Kebersihan ruangan yang tidak terjaga.

e.Organisasi:

(1) Pengambilan keputusan masih belum sepenuhnya wewenang dari ketua STMIK Dharma Negara.

(2) Tidak adanya badan organisasi yang berfungsi untuk mengevaluasi berbagai kegiatan di STMIK Dharma Negara.

(3) Masih adanya rangkap jabatan dalam melakukan proses bisnis pada STMIK Dharma Negara.

f. Teknologi informasi dan sistem informasi:

(1) STMIK Dharma Negara belum mengoptimalkan teknologi informasi dalam mendukung proses bisnis yang berlangsung.

(2) Belum terintegrasinya sistem informasi yang digunakan dalam mendukung proses bisnis STMIK Dharma Negara.

3) Opportunities (peluang).

Peluang adalah suatu kesempatan yang baik, yang apabila diambil maka akan mendapat keuntungan bagi STMIK Dharma Negara.

Peluang di STMIK Dharma Negara:

(1) Membentuk lulusan yang kompeten, inovatif, dan profesional, berwawasan luas serta memiliki penguasaan yang mendalam dalam bidang ilmu yang menjadi keahliannya dan mampu mengamalkan ilmu yang dimilikinya untuk kepentingan masyarakat dan perusahaan.

(2) Untuk membentuk lulusan seperti pada poin nomor satu di atas dilakukan upaya seperti pemberian buku panduan, diskusi, pelatihan lapangan, lab multi, online kampus, UKM (paduan suara, fotography, radio, seni budaya, olahraga dll).

(3) Dan peluang yang sangat besar di STMIK Dharma Negara yaitu penyaluran kerja mudah, bila mahasiswa/mahasiswi yang berprestasi contohnya di Perbankan, perusahaan swasta, dan bidang pendidikan.

(4) Menciptakan Perguruan Tinggi Swasta agar memiliki kepekaan terhadap sumber daya alam, sehingga bisa membuat kota Bandung menjadi semakin juara.

\section{4) Threats (tantangan).}

Tantangan merupakan hambatan atau halangan yang dimana akan menghalangi langkah dari STMIK Dharma Negara untuk mencapai tujuan yang direncanakan.

Tantangan bagi STMIK Dharma Negara yaitu:

a. Perguruan tinggi negeri yang mempunyai fasilitas yang lebih komplit.

b. Lulusan SMA/SMK lebih tertarik masuk ke Perguruan Tinggi Negeri di bandingkan ke Perguruan Tinggi Swasta. c. Semakin banyaknya Perguruan Tinggi Swasta yang memiliki jurusan informatika dan Komputer.

d. Tanggung jawab moral oleh para alumni, karena apabila alumni melakukan pelanggaran dalam pekerjaannya, maka secara otomatis perusahaanperusahaan tersebut tidak ingin lagi menggunakan jasa tenaga kerja yang berasal dari STMIK Dharma Negara.

e. Apabila mahasiswa STMIK Dharma Negara melakukan tindak kriminal, maka itu akan mencoreng nama baik STMIK Dharma Negara dikalangan masyarakat, yang mengakibatkan para orang tua tidak mengizinkan calon mahasiswa untuk melanjutkan studinya di STMIK Dharma Negara.

\section{Fase Arsitektur Visi}

Pada fase ini akan dijabarkan keadaan organisasi STMIK Dharma Negara dari segi organisasi maupun dari segi teknologi yang digunakan

1) Profil Organisasi

Yayasan Dharma Negara (YDN) didirikan oleh Drs. Syamsir Alamsyah dengan Akta Notaris Herlie Sumanpow, No: 4 Tanggal 4 September 1972. AKPI didirikan pada tahun 1977 dan berkembang menjadi STIE AKPI pada tahun 2000, dan pada tahun 2005 menjadi STIE Dharma Negara. Pada tahun 1994 YDN mendirikan Poltek PMBI kemudian berubah menjadi STMIK PMBI pada tahun 1996. Pada tahun 2005 menjadi STMIK Dharma Negara baik STIE AKPI \& STMIK PMBI mengalami kemajuan yang sangat pesat. Pada tahun 2004 YDN berganti kepengurusan kepada Abdul Djalil Matondang S.H sebagai Ketua Dewan Pembina dengan Akta Notaris Hildayanti, SH, Nomor: 2 Tanggal 29 September 2004.

2) Visi Dan Misi Organisasi

Visi: Mencetak manusia seutuhnya (A whole person) yang cerdas intelektual (Intellectual Quotient), fisikal (Physical Quotient), emosional (Emotional Quotient) dan spiritual (Spiritual Quotient) untuk terus berprestasi dan berkontribusi dalam segala aspek kehidupan.

Misi: (1) Mencetak generasi unggulan baik sebagai profesional maupun entrepreneur yang memiliki integritas dan daya saing global.

(2) Mengembangkan institusi dengan tata kelola organisasi terbaik (Good Governance) yang menjadi katalisator dan inspirator bagi pengembangan masyarakat madani.

(3) Meningkatkan shareholder value dalam pengembangan institusi yang berkelanjutan (sustainable development).

(4) Meningkatkan employee value dengan budaya kerja yang inspiring dan menyenangkan. 


\section{3) Tujuan Organisasi}

Tujuan:

(1) Menghasilkan lulusan yang beriman, bertakwa, menguasai IPTEK, profesional, kreatif, inovatif, bertanggung jawab dan mandiri.

(2) Meningkatkan dan menghasilkan kegiatan penelitian sebagai landasan penyelenggaraan pendidikan dan pengembangan IPTEK.

(3) Mewujudkan pengelolaan yang terencana, terorganisasi produktif, efektif, efesien dan terpercaya untuk menjamin keberlanjutan perguruan tinggi.

(4) Menjalin kerjasama dengan pihak lain dalam lingkungan regional, nasional dan internasional untuk pengembangan pendidikan dan penelitian.

(5) Mewujudkan sifitas akademik yang mampu menjadi teladan dalam kehidupan bermasyarakat.

\section{4) Struktur Organisasi}

Struktur organisasi berfungsi sebagai alat untuk menjadikan berbagai unit/bagian dari STMIK Dharma Negara dapat bekerja secara profesional dan proporsional. Struktur organisasi dari STMIK Dharma Negara seperti yang terlihat di gambar 5 .

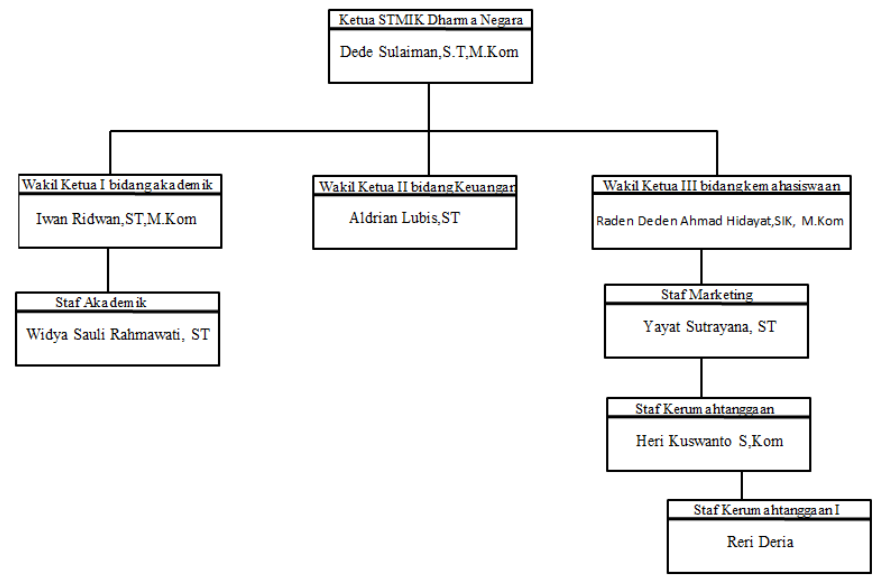

Gambar 5. Struktur Organisasi STMIK Dharma Negara

\section{5) Proses Bisnis}

STMIK Dharma Negara merupakan organisasi yang mempunyai bisnis utama di bidang pendidikan. Saat ini jenjang pendidikan yang dikelola oleh STMIK Dharma Negara adalah perguruan tinggi strata 1, diploma III, diploma II, diploma I. Pemetaan proses bisnis STMIK Dharma Negara dilakukan berdasarkan struktur organisasi dan kegiatan yang dilakukan. Kemudian hasil pemetaan proses bisnis akan di analisa apakah sudah sesuai dengan tujuan organisasi berdasarkan pada visi dan misi nya.

\section{6) Kondisi Arsitektur Saat Ini}

Pada tahap ini adalah mendokumentasikan dan mendefinisikan seluruh sistem dan teknologi yang digunakan oleh STMIK Dharma Negara. STMIK Dharma Negara memiliki sistem informasi yang digunakan untuk mengolah berbagai pekerjaan tertentu. Sistem informasi yang digunakan oleh STMIK Dharma Negara saat ini belum terintegrasi antara aplikasi yang satu dengan aplikasi yang lainnya, perbedaan platform yang digunakan untuk membangun sistem informasi pada STMIK Dharma Negara merupakan salah satu kendala yang menjadikan sistem informasi tidak dapat digunakan secara maksimal.

\section{(1) Kondisi Arsitektur Sistem Informasi Saat Ini}

Keterbatasan wewenang dari manajemen STMIK Dharma Negara dalam mengambil keputusan juga merupakan kendala untuk mengembangkan sistem informasi dan arsitektur enterprise di STMIK Dharma Negara. Adapun sistem informasi yang digunakan saat ini adalah:
a. Sistem informasi akademik.
b. Sistem informasi penerimaan mahasiswa baru.
c. Sistem informasi karyawan.

(2) Kondisi Arsitektur Teknologi saat ini

Selain sistem informasi STMIK Dharma Negara juga menggunakan jaringan komputer guna mendukung proses bisnis yang berjalan di STMIK Dharma Negara. Jaringan komputer yang digunakan di STMIK Dharma Negara terdiri dari satu jaringan lokal yang dihubungkan dengan jaringan internet melalui salah satu provider yang ada di kota Bandung. Penggunaan jaringan komputer ini diperuntukkan untuk mendukung proses bisnis sehingga tujuan utama dari STMIK Dharma Negara dapat tercapai.

- Perangkat Keras dan Perangkat Lunak saat ini:

(a) Personal Computer:

- Kapasitas memori 2 GB.

- Kapasitas hardisk: $250 \mathrm{~GB}$.

- Jenis processor: intel core i3 dengan kecepatan 3,2 GHz.

(b) Printer: Printer ink-jet.

(c) Infrastruktur Teknologi Dan Jaringan Komputer.

- Mikrotik RB 750.

- Acces Point D link

- Provider internet: Telkom

- Bandwidth: $2 \mathrm{M}$

- Switch / Hub

(d) Sistem Operasi: Windows 7, Windows 8.

- Teknologi dan Topologi Jaringan Komputer STMIK Dharma Negara saat ini

Jaringan komputer pada STMIK Dharma Negara saat ini menggunakan jaringan dial up dari Telkom dengan bandwith 
2M. Topologi jaringan komputer pada STMIK Dharma Negara saat ini dapat dilihat pada gambar 6 di bawah ini.

\section{Fase Arsitektur Bisnis}

Analisis value chain digunakan pada fase ini untuk mengetahui proses bisnis apa saja yang terjadi di STMIK Dharma Negara serta di jabarkan pula hubungan antara proses bisnis dan unit organisasi yang ada saat ini. Di fase ini juga diusulkan perubahan terhadap struktur organisasi yang didasarkan pada analisis SWOT yang dilakukan pada fase Preliminary.

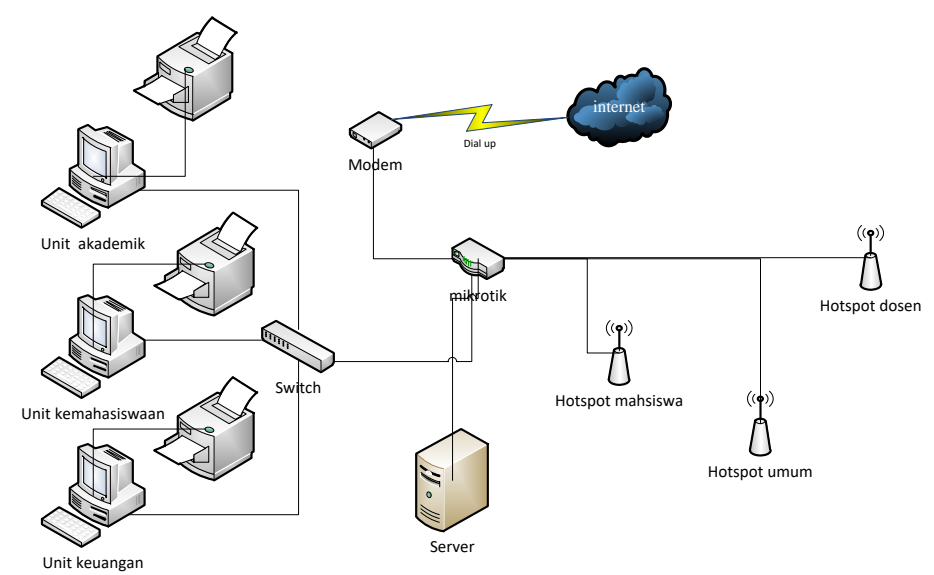

Gambar 6. Topologi jaringan STMIK Dharma Negara saat ini

\section{1) Analisis Value Chain}

STMIK Dharma Negara merupakan organisasi yang mempunyaai proses bisnis utama di bidang pendidikan berkeinginan kuat untuk selalu dapat menjaga kerja sama dengan setiap stakeholder yang terlibat. Pada sub bab ini penulis coba menggambarkan dan mengembangkan poses bisnis dan unit/bagian di STMIK Dharma Negara, selain itu pada sub bab ini juga di gambarkan bagaimana hubungan antara STMIK Dharma Negara dengan setiap stakeholder yang terlibat didalamnya dengan menggunakan value chain analisis seperti yang terlihat di gambar 7 .

Dari gambar hasil analisis value chain yang dilakukan seperti gambar diatas maka proses bisnis pada STMIK Dharma Negara dibagi menjadi dua bagian aktifitas yaitu aktifitas utama dan aktifitas pendukung. Dari kedua aktifitas tersebut penulis membuat matrik hubungan antara unit organisasi yang ada dengan proses bisnis yang terdi di STMIK Dharma Negara.

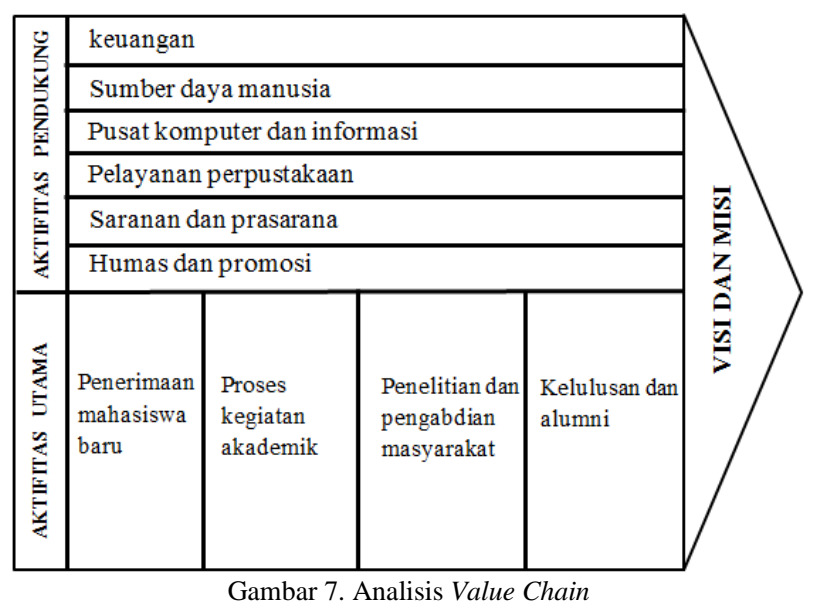

\section{2) Usulan Struktur Organisasi}

Agar tercapainya visi, misi dan tujuan dari STMIK Dharma Negara, sebaiknya dilakukan reorganisasi dari yang sebelumnya. Reorganisasi ini dimaksudkan agar setiap unit dari STMIK Dharma Negara dapat bekerja secara profesional dan proporsional. Dari hasil analisis SWOT pada fase preliminary penulis merancang usulan struktur organisasi yang dapat diterapkan oleh STMIK Dharma Negera dapat dilihat pada gambar 8 di bawah ini.

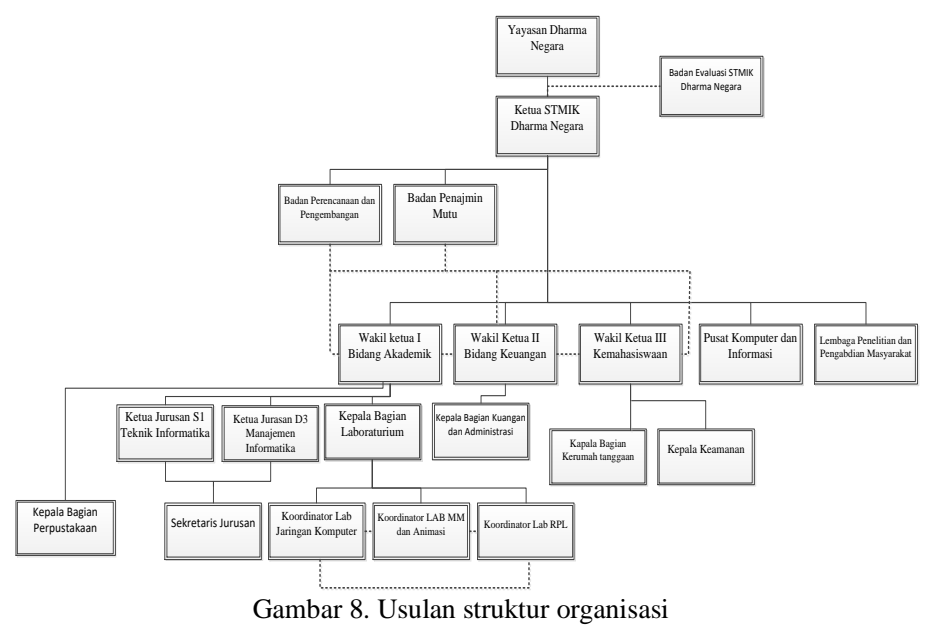

Pada bab ini juga dihasilkan matrik hubungan antara proses bisnis yang telah dijabarkan menggunakan nalisis value chain dengan struktur organisasi usulan, yang akan diterapkan pada penelitian ini.

\section{E. Fase Arsitektur Sistem Informasi}

Pada tahapan ini kegiatan yang dilakukan adalah menentukan arsitektur data dan arsitektur sistem informasi yang digunakan untuk proses bisnis pada STMIK Dharma Negara. 


\section{3) Arsitektur Data}

Pada sub bab ini, penulis menggambarkan kebutuhan entitas yang nantinya akan dimodelkan dengan menggunakan class diagram.

\section{(a) Kandidat Entitas}

Penentuan kandidat entitas dapat diambil dari analisis value chain yang telah di gambarkan di atas. Rincian entitas dapat dilihat pada tabel 1 di bawah ini.

Tabel 1. Entitas Data

\begin{tabular}{|c|c|}
\hline Kandidat Entitas & Entitas \\
\hline Penerimaan mahasiswa baru & $\begin{array}{l}\text { 1) calon_mhs_baru } \\
\text { 2) ujian_masuk } \\
\text { 3) hasil_ujian }\end{array}$ \\
\hline Proses kegiatan akademik & $\begin{array}{l}\text { 1) mhs } \\
\text { 2) jurusan } \\
\text { 3) mata_kuliah } \\
\text { 4) ruangan } \\
\text { 5) dosen } \\
\text { 6) jadwal_kuliah } \\
\text { 7) jadwal_lab } \\
\text { 8) nilai_matkul } \\
\text { 9) khs }\end{array}$ \\
\hline $\begin{array}{l}\text { Penelitian dan pengabdian } \\
\text { masyarakat }\end{array}$ & $\begin{array}{l}\text { 1) penelitian } \\
\text { 2) kegiatan_masyarakat }\end{array}$ \\
\hline Kelulusan dan alumni & $\begin{array}{l}\text { 1) wisuda } \\
\text { 2) data_alumni }\end{array}$ \\
\hline Keuangan & $\begin{array}{l}\text { 1) honor_dosen } \\
\text { 2) honor_karyawan } \\
\text { 3) iuran_mhs } \\
\text { 4) data_keuangan } \\
\text { 5) honor_dosentetap }\end{array}$ \\
\hline Sumber daya manusia & $\begin{array}{l}\text { 1) dosen } \\
\text { 2) karyawan } \\
\text { 3) peniliain_kinerja_dosen } \\
\text { 4) } \\
\text { penilain_kinerja_karyawan } \\
\text { 5) jabatan }\end{array}$ \\
\hline $\begin{array}{l}\text { Pusat komputer dan } \\
\text { informasi }\end{array}$ & $\begin{array}{l}\text { 1) inventaris_it } \\
\text { 2) Pengadaan_perangkatit } \\
\text { 3) pemeliharan_it }\end{array}$ \\
\hline Pelayanan perpustakaan & $\begin{array}{l}\text { 1) buku } \\
\text { 2) peminjaman buku } \\
\text { 3) pengembalian buku }\end{array}$ \\
\hline Sarana dan prasarana & $\begin{array}{l}\text { 1) inventaris } \\
\text { 2) pemeliharaan_barang } \\
\text { 3) pengadaan_barang } \\
\text { 4) sarana_prasarana }\end{array}$ \\
\hline Humas dan promosi & 1) promosi \\
\hline
\end{tabular}

\section{(b) Class Diagram}

Class diagaram digunakan untuk memodelkan entitas, atribut dan relasi dari kandidat-kandidat entitas yang telah di jabarkan pada tabel 2 di atas. Pemodelan menggunakan class diagram dapat dilihat pada gambar 9 di bawah ini.

Pada subbab ini juga penulis menggambarkan hubungan anatara entitas data dengan proses bisnis yang terjadi di STMIK Dharma Negara.

\section{4) Arsitektur Aplikasi}

Pada arsitektur aplikasi ini bertujuan untuk mendefinisikan jenis aplikasi utama yang telah bekerja secara terintegrasi antara satu aplikasi dengan aplikasi yang lainnya. Aplikasi-aplikasi ini dibutuhkan untuk mengelola data dan mendukung proses bisnis di STMIK Dharma Negara, dalam tahap ini pula mendefinisikan aplikasi apa saja yang dibutuhkan untuk mengelola data dan menyediakan informasi bagi pengguna untuk melakukan proses bisnis.

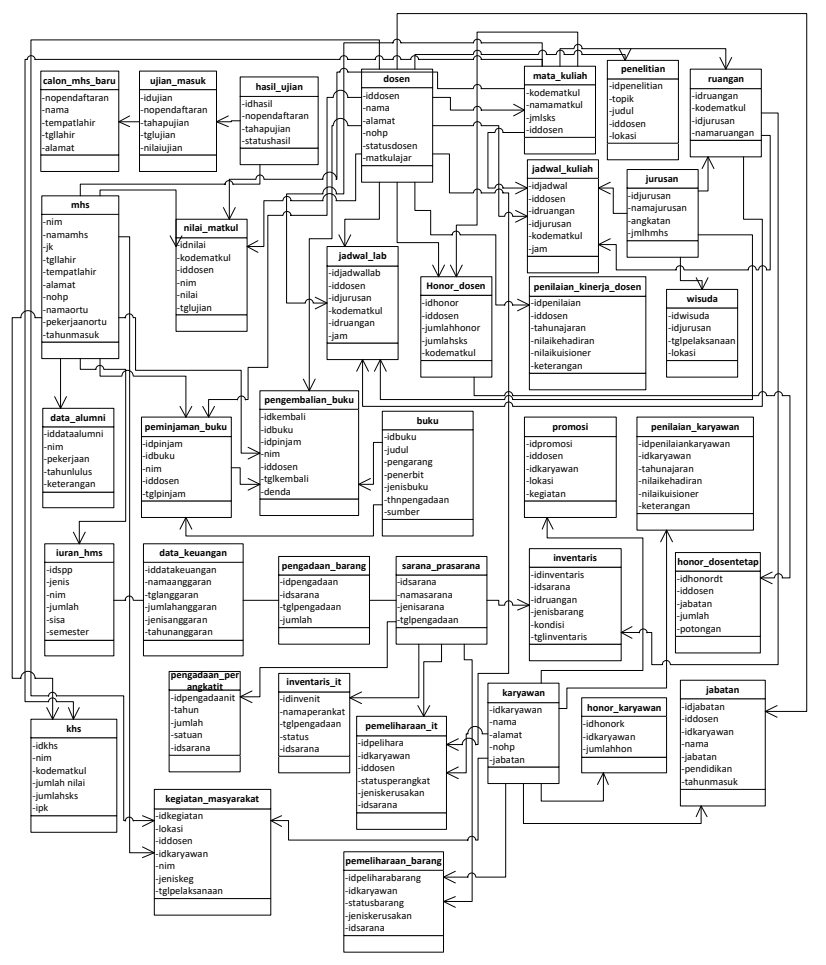

Gambar 9. Class diagram

(a) Kandidat Aplikasi Yang Dapat Digunakan

Matrik hubungan entitas data dengan fungsi bisnis dapat digunakan untuk merencanakan aplikasi berorientasi pada data dan fungsi bisnis. Kelompok penggunaan data yang menciptakan data tertentu akan membentuk kelompok 
kandidat aplikasi yang digunakan untuk mendukung proses bisnis di STMIK Dharma Negara.

Tabel 2. Pemetaan kebutuhan aplikasi

\begin{tabular}{|c|c|c|c|}
\hline No & Kelompok Aplikasi & No & Paket Aplikasi \\
\hline 1. & $\begin{array}{l}\text { Sistem informasi } \\
\text { penerimaan } \\
\text { mahasiswa baru }\end{array}$ & $\begin{array}{l}1 . \\
2 . \\
3 .\end{array}$ & $\begin{array}{c}\text { Aplikasi pendaftaran } \\
\text { mahasiswa baru } \\
\text { Aplikasi ujian masuk } \\
\text { Aplikasi daftar ulang }\end{array}$ \\
\hline 2. & $\begin{array}{l}\text { Sistem informasi } \\
\text { akademik }\end{array}$ & $\begin{array}{l}4 . \\
5 . \\
6 . \\
7 . \\
8 . \\
9 . \\
9 .\end{array}$ & $\begin{array}{l}\text { Aplikasi mahasiswa } \\
\text { Aplikasi penentuan } \\
\text { matakuliah } \\
\text { Aplikasi penentuan } \\
\text { ruangan } \\
\text { Aplikasi penentuan } \\
\text { jadwal kuliah } \\
\text { Aplikasi penentuan jadwl } \\
\text { LAB } \\
\text { Aplikasi nilai matakuliah } \\
\text { Aplikasi KHS }\end{array}$ \\
\hline 3. & $\begin{array}{l}\text { Sistem informasi } \\
\text { penelitian dan } \\
\text { pengabdian } \\
\text { masyarakat }\end{array}$ & $\begin{array}{l}11 . \\
12 .\end{array}$ & $\begin{array}{l}\text { Aplikasi kegiatan } \\
\text { penelitian } \\
\text { Aplikasi kegiatan } \\
\text { masyarakat }\end{array}$ \\
\hline 4. & $\begin{array}{l}\text { Sistem informasi } \\
\text { alumni }\end{array}$ & $\begin{array}{l}13 . \\
14 .\end{array}$ & $\begin{array}{l}\text { Aplikasi wisuda } \\
\text { Aplikasi alumni }\end{array}$ \\
\hline 5. & $\begin{array}{l}\text { Sistem informasi } \\
\text { keuangan }\end{array}$ & $\begin{array}{l}15 . \\
16 . \\
17 \\
18 . \\
19 .\end{array}$ & $\begin{array}{l}\text { Aplikasi penggajian } \\
\text { dosen } \\
\text { Aplikasi penggajian } \\
\text { karyawan } \\
\text { Aplikasi pembayaran } \\
\text { mahasiswa } \\
\text { Aplikasi data keuangan } \\
\text { Aplikasi data dosen tetap }\end{array}$ \\
\hline 6. & $\begin{array}{l}\text { Sistem informasi } \\
\text { sumber daya } \\
\text { manusia }\end{array}$ & $\begin{array}{l}20 . \\
21 . \\
22 . \\
23 \\
24 .\end{array}$ & $\begin{array}{l}\text { Aplikasi data dosen } \\
\text { Aplikasi data karyawan } \\
\text { Aplikasi penilaian } \\
\text { kinerja dosen } \\
\text { Aplikasi penilaian } \\
\text { kinerja karyawan } \\
\text { Aplikasi jabatan }\end{array}$ \\
\hline 7. & $\begin{array}{l}\text { Sistem informasi } \\
\text { pusat komputer dan } \\
\text { informasi }\end{array}$ & $\begin{array}{l}25 . \\
26 . \\
27 .\end{array}$ & $\begin{array}{l}\text { Aplikasi investasi IT } \\
\text { Aplikasi pengadaan IT } \\
\text { Aplikasi pemeliharaan IT }\end{array}$ \\
\hline 8. & $\begin{array}{l}\text { Sistem informasi } \\
\text { sarana dan } \\
\text { prasarana }\end{array}$ & $\begin{array}{l}28 . \\
29 . \\
30 . \\
31 .\end{array}$ & $\begin{array}{l}\text { Aplikasi investasi } \\
\text { Aplikasi pemeliharaan } \\
\text { barang } \\
\text { Aplikasi pengadaan } \\
\text { barang } \\
\text { Aplikasi sarana dan } \\
\text { prasarana }\end{array}$ \\
\hline 9. & $\begin{array}{l}\text { Sistem informasi } \\
\text { perpustakaan }\end{array}$ & $\begin{array}{l}32 . \\
33 .\end{array}$ & Aplikasi buku \\
\hline
\end{tabular}

\begin{tabular}{|c|l|c|l|}
\hline & & 34. & $\begin{array}{l}\text { Aplikasi peminjaman } \\
\text { buku } \\
\text { Aplikasi pengembalian } \\
\text { buku }\end{array}$ \\
\hline 10. & $\begin{array}{l}\text { Sistem informasi } \\
\text { promosi }\end{array}$ & 35. & Aplikasi promosi \\
\hline
\end{tabular}

F. Fase Arsitektur Tekonologi

Arsitektur teknologi pada STMIK Dharma Negara menggambarkan infrastruktur 'landscape' fisik atau perangkat keras dan jaringan komputer yang mendukung keberlangsungan proses bisnis di STMIK Dharma Negara. Arsitektur teknologi merepresentasikan hubungan antara komponen perangkat keras yang digunakan dalama infrastruktur fisik sistem informasi. Arsitektur ini juga dapat digunakan untuk mempresentasikan komponen perangkat lunak.

\section{1) Arsitektur Teknologi STMIK Dharma Negara yang diusulkan} Arsitektur teknologi STMIK Dharma Negara yang diusulkan terdiri dari perangkat keras, perangkat lunak dan topologi jaringan yang akan digunakan.

\section{2) Topologi Jaringan Yang Diusulkan}

Untuk mendukung berbagai aktifitas STMIK Dharma Negara. Bandwidth jaringan internet yang awalnya hanya sebesar $2 \mathrm{M}$ diusulkan untuk ditambah menjadi $5 \mathrm{M}$. Penambahan bandwidth ini dikarenakan adanya penambahan unit organisasi pada struktur organisasi yang diusulkan pada STMIK Dharma Negara. Selain itu pada perancangan teknologi yang digunakan sudah menggunakan cloud computing yang bertujuan sebagai tempat tersimpannya data dan diharapkan dapat meningkatkan keamanan dan fleksibilitas dalam menggunakan data. Penggunaan cloud computing ini juga dapat mengefiensikan biaya pemeliharaan server yang ada pada teknologi yang digunakan saat ini. Gambar 10 memperlihatkan usulan topologi jaringan komputer.

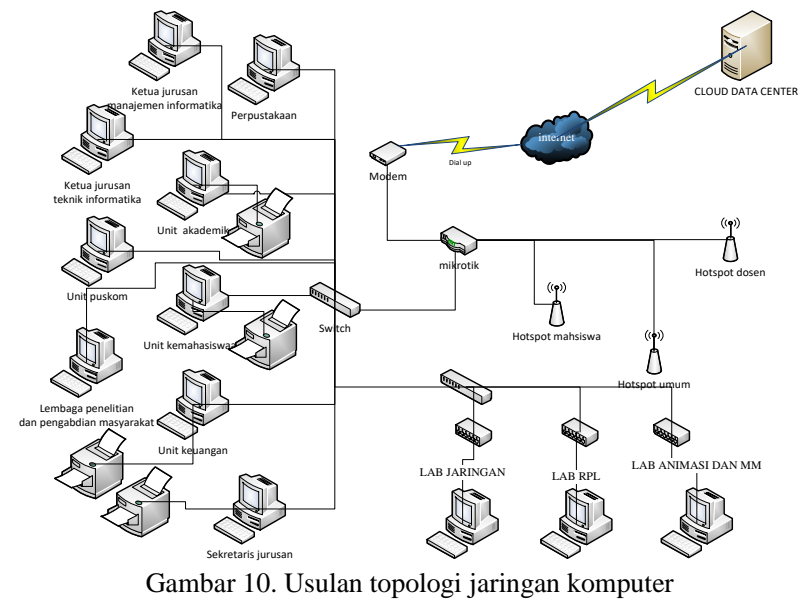




\section{G. Fase Peluang dan Solusi}

Seperti yang telah di jabarkan pada halaman-halaman sebelumnya. Terdapat gap antara keadaan arsitektur saat ini dengan usual enterprise yang akan di kembangkan. Perbandingan antara arsitektur yang berjalan saat ini dengan arsitektur enterprise yang akan dikembangkan dapat dilihat pada tabel-tabel di bawah ini.

Perbandingan Struktur Organisasi Saat Ini Dengan Struktur Organisasi Yang Diusulkan.

Dalam memaksimalkan pencapaian visi misi dan tujuan pada STMIK Dharma Negara. Penulis mencoba melakukan perubahan pada struktur organisasi yang sedang berjalan saat ini. Perbedaan antara struktur organisasi yang berjalan dengan struktur organisasi yang penulis ajukan terdapat pada tabel 3 di bawah ini.

Tabel 3. Perbandingan struktur organisasi yang berjalan dan struktur organisasi

\begin{tabular}{|c|c|}
\hline $\begin{array}{c}\text { Unit pada struktur } \\
\text { organisasi yang } \\
\text { berjalan }\end{array}$ & $\begin{array}{c}\text { Unit pada struktur organisasi } \\
\text { yang diusulkan }\end{array}$ \\
\hline $\begin{array}{l}\text { 1. Ketua STMIK } \\
\text { Dharma Negara } \\
\text { 2. Wakil Ketua I } \\
\text { Bidang } \\
\text { Akademik } \\
\text { 3. Wakil Ketua II } \\
\text { Bidang } \\
\text { Keuangan } \\
\text { 4. Wakil Ketua III } \\
\text { Bidang } \\
\text { Kemahasiswaan } \\
\text { 5. Staf Akademik } \\
\text { 6. Staf Marketing } \\
\text { 7. Staf Kerumah } \\
\text { tanggaan }\end{array}$ & $\begin{array}{l}\text { 1. Yayasan Dharma Negara } \\
\text { 2. Badan Evaluasi STMIK } \\
\text { Dharma Negara } \\
\text { 3. Ketua STMIK Dharma } \\
\text { Negara } \\
\text { 4. Badan Penjamin Mutu } \\
\text { 5. Badan Perancangan dan } \\
\text { Pengembangan } \\
\text { 6. Wakil Ketua I Bidang } \\
\text { Akademik } \\
\text { 7. Wakil Ketua II Bidang } \\
\text { Keuangan } \\
\text { 8. Wakil Ketua } \\
\text { Kemahasiswaan } \\
\text { 9. Ketua Pusat Komputer dan } \\
\text { Informasi } \\
\text { 10. Ketua Lembaga Penelitian } \\
\text { dan Pengabdian masyarakat } \\
\text { 11. Kepala } \\
\text { Perpustakaan } \\
\text { 12. Ketua Jurusan S1 Teknik } \\
\text { Informatika } \\
\text { 13. Ketua Jurusan } \\
\text { manajemen Informatika } \\
\text { 14. Kepala } \\
\text { Laboraturium } \\
\text { 15. Kepala Bagian } \\
\text { Kerumahtanggaan } \\
\text { 16. Sekretaris Jurusan } \\
\text { 17. Koordinator Lab Jaringan } \\
\text { Komputer }\end{array}$ \\
\hline
\end{tabular}

\begin{tabular}{|l|l|}
\hline & $\begin{array}{l}\text { 18. Koordinator Lab MM dan } \\
\text { Animasi } \\
\text { 19. Koordinator Lab RPL } \\
\text { 20. Kepala Keamanan }\end{array}$ \\
\hline
\end{tabular}

\section{H. Perencanaan Migrasi/Migration Planning}

Fase Migration planning memiliki tujuan untuk merencanakan proses migrasi atau peralihan dari keadaan di STMIK Dharma Negara saat ini ke usulan rancangan arsitektur enterprise agar penerapan arsitektur enterprise yang akan dibangun menjadi terarah dan berjalan dengan baik. Proses migrasi ini melalui rencana roadmap implementasi seperti pada tabel 4 berikut ini.

Tabel 4. Roadmap implementasi arsitektur enterprise

\begin{tabular}{|c|c|c|c|}
\hline No & $\begin{array}{c}\text { Fase } \\
\text { pengembangan } \\
\text { arsitektur } \\
\text { enterprise }\end{array}$ & $\begin{array}{l}\text { Paket } \\
\text { aplikasi }\end{array}$ & $\begin{array}{c}\text { Tahap } \\
\text { pengembangan } \\
\text { arsitektur } \\
\text { enterprise }\end{array}$ \\
\hline 1 & Arsitektur visi & & Tahap I \\
\hline 2 & $\begin{array}{l}\text { Arsitektur sistem } \\
\text { informasi }\end{array}$ & $\begin{array}{l}\text { Arsitektur } \\
\text { sistem } \\
\text { informasi }\end{array}$ & Tahap II \\
\hline 3 & & $\begin{array}{l}\text { Sistem } \\
\text { informasi } \\
\text { penerimaan } \\
\text { mahasiswa } \\
\text { baru }\end{array}$ & Tahap III \\
\hline 4 & & $\begin{array}{l}\text { Sistem } \\
\text { informasi } \\
\text { akademik }\end{array}$ & Tahap IV \\
\hline 5 & & $\begin{array}{l}\text { Sistem } \\
\text { informasi } \\
\text { penelitian } \\
\text { dan } \\
\text { pengabdian } \\
\text { masyarakat }\end{array}$ & Tahap V \\
\hline 6 & & $\begin{array}{l}\text { Sistem } \\
\text { informasi } \\
\text { alumni }\end{array}$ & Tahap VI \\
\hline 7 & & $\begin{array}{l}\text { Sistem } \\
\text { informasi } \\
\text { keuangan }\end{array}$ & Tahap VII \\
\hline 8 & & $\begin{array}{l}\text { Sistem } \\
\text { informasi } \\
\text { sumber daya } \\
\text { manusia }\end{array}$ & Tahap VIII \\
\hline 9 & & $\begin{array}{l}\text { Sistetm } \\
\text { informasi } \\
\text { pusat } \\
\text { komputer } \\
\text { dan } \\
\text { informasi }\end{array}$ & Tahap IX \\
\hline
\end{tabular}




\begin{tabular}{|c|c|c|c|}
\hline 10 & & $\begin{array}{l}\text { Sistem } \\
\text { informasi } \\
\text { sarana dan } \\
\text { prasarana }\end{array}$ & Tahap X \\
\hline 11 & & $\begin{array}{l}\text { Sistem } \\
\text { informasi } \\
\text { perpustakaa } \\
n\end{array}$ & Tahap XI \\
\hline 12 & & $\begin{array}{l}\text { Sistem } \\
\text { informasi } \\
\text { promosi }\end{array}$ & Tahap XII \\
\hline 13 & $\begin{array}{l}\text { Arsitektur } \\
\text { Teknologi }\end{array}$ & & Tahap XIII \\
\hline
\end{tabular}

\section{KESIMPULAN DAN SARAN}

\section{A. Kesimpulan}

Kesimpulan yang dapat di ambil berdasarkan tahapan perancangan arsitektur enterprise menggunakan TOGAF ADM pada penelitian ini adalah sebagai berikut:

(1) penelitian ini menghasilkan perancangan arsitektur enterprise untuk mendukung proses bisnis di STMIK Dharma Negara.

(2) Dari analisa awal menggunakan analisa SWOT pada fase preliminary menggambarkan adanya beberapa kekurangan pada STMIK Dharma Negara. Kelemahan-kelemahan tersebut dijadikan acuan bagi peneliti untuk mengembangkan fase selanjutnya dari fase-fase arsitektur enterprise dengan menggunakan TOGAF ADM.

(3) Pada fase arsitektur visi dan arsitektur bisnis yang di usulkan terdapat perubahan yang sangat besar dari keadaan yang berjalan saat ini. Hal ini disebabkan karena penulis beranggapan bahwa untuk mencapai visi dan misi serta tujuan berdirinya STMIK Dharma Negara, maka yang menjadi kelemahan dan kekurangan dari STMIK Dharma Negara harus di minimalkan. Salah satu perubahan pada fase arsitektur visi dan arsitektur bisnis adalah terciptanya struktur organisasi baru dan bertambahnya proses unit organisasi yang mendukung proses bisnis dari STMIK Dharma Negara.

(4) Pada fase berikutnya dihasilkannya sistem informasi yang terintegrasi yang terdiri dari sepuluh sistem informasi yaitu sistem informasi penerimaan mahasiswa baru, sistem informasi akademik, sistem informasi penelitian dan pengabdian masyarakat, sistem informasi alumni, sistem informasi keuangan, sistem informasi SDM, sistem informasi pusat komputer dan informasi, sistem informasi sarana dan prasarana, sistem informasi perpustakaan dan sistem informasi promosi, sebelumnya STMIK Dharma Negara hanya menggunakan tiga sistem informasi namun ketiga sistem informasi tersebut belum terintegrasi satu dan yang lainnya. Selain itu teknologi informasi telah di rancang untuk mendukung proses bisnis pada STMIK Dharma Negara.

(5) Pada penelitian ini juga menghasilkan perencanaan migrasi arsitektur enterprise yang telah di rancang berdasarkan fase fase pada arsitektur enterprise yang di usulkan untuk tercapainya tujuan utama berdirinya STMIK Dharma Negara.

\section{B. Saran}

Perancangan arsitektur enterprise pada penelitian ini tentunya masih memerlukan masukan dari berbagai pihak. Adapun saran dari penelitian ini adalah sebagai berikut:

(1) Penerapan arsitektur enterprise membutuhkan keseriusan dari setiap stakeholder dari STMIK Dharma Negara.

(2) Perancangan arsitektur enterprise hanya menggunakan tujuh fase dari sembilan fase TOGAF ADM, masih dua fase lagi yang belum di lakukan yaitu implementation governance dan architecture change management.

(3) untuk memperoleh arsitektur enterprise yang lebih sempurna maka dibutuhkan kajian lebih lanjut terhadap setiap fase dari penelitian ini.

\section{Daftar pustaka}

[1] Kadir A (2014). Pengenalan Sistem Informasi Edisi Revisi. Yogyakarta: Andi Offset.

[2] Kristanto A (2007). Perancangan Sistem Informasi dan Aplikasinya. Yogyakarta: Gava Media.

[3] Minoli D (2008). Enterprise Architecture A To Z. Taylor \& Francis Group, LLC.

[4] The Open Group (2009). TOGAFTM Version 9 Foundation Study Guide

Preparation for the TOGAF 9 Part 1 Examination. Van Haren Publishing, Zaltbommel.www.vanharen.net

[5] Booch G, Rumbaugh J, Jacobson I (2005). The Unified Modeling Language User Guide SECOND EDITION. Addison Wesley Professional.

[6] A.S Rosa, Shalahuddin M (2015). Rekayasa Perangkat Lunak Terstruktur dan Berorientasi Objek. Bandung. Informatika Bandung

[7] Lusa, Sensuse (2011). Kajian Pengembangan Dan Usulan Perancangan Enterprise Architektur Framework: Seminar Nasional Aplikasi Teknologi Informasi; Yogyakarta, 17 - 18 Juni 2009

[8] Fowler M, Scott K (1999). UML Distilled Second Edition A Brief Guide to the Standard Object Modeling Language. Addison Wesley

[9] Wahono RS, Dharwiyanti S (2003). Pengantar Unified Modeling Language (UML). Kuliah Umum IlmuKomputer.com

[10] Setiawan R (2015). Perancangan Arsitektur Enterprise ESttg Menggunakan Togaf Adm Di Sekolah Tinggi Teknologi Garut. ISSN: 2302-7339 Vol. 12 No. 12015

[11] Wikipedia Indonesia. "Rantai Nilai ”. 25 Desember 2015. 
https://id.wikipedia.org/wiki/Rantai_nilai

[12] Porter M. 1985, Competitive Advantage: Creating and Sustaining Superior Performance for Analyzing Industries and Competitor, The Free Press.

[13] Er Augury, Rahayu S. (2012). Pengolahan data warehouse akademik sebagai penunjang keputusan di perguruan tinggi. Konferensi Nasional Sistem Informasi 2012, Nomor Makalah 055, Halaman 238

[14] Zulaiha S. (2009). Perancangan Enterprise Architecture Menggunakan Togaf Di Direktorat Jenderal Perbendaharaan Departemen Keuangan. Tesis 2009, Institut Teknologi Bandung

[15] Wiley J, Sons. (2001) EXECUTIVE STRATEGY Strategic Management and Information Technology. Inc. New York.

[16] Cabrera A, Abad M, Jaramillo D, Gomez J, Verdum JC.

(2015). Definition and Implementation of the Enterprise Business Layer Through a Business Reference Model, Using the Architecture Development Method ADMTOGAF. 